\author{
Ali Abid Abojassim ${ }^{1}$, , Hussien Abid Ali Mraity ${ }^{1}$, Afnan Ali Husain ${ }^{1}$, Mike Wood ${ }^{2}$ \\ ${ }^{1}$ University of Kufa, Faculty of Science, Department of Physics, Kufa, Iraq \\ ${ }^{2}$ School of Environment \& Life Sciences, University of Salford, United Kingdom
}

*Corresponding author: ali.alhameedawi@uokufa.edu.iq

\title{
ESTIMATION OF THE EXCESS LIFETIME CANCER RISK FROM RADON EXPOSURE IN SOME BUILDINGS OF KUFA TECHNICAL INSTITUTE, IRAQ
}

A number of international health organizations consider the exposure to residential radon as the second main cause of lung cancer after cigarette smoking. For this, it was found that there is no data base on radon concentrations for the Kufa Technical Institute buildings in literature. This therefore triggers a special need for radon measurement in some Kufa Technical Institute buildings. This study aims to investigate the indoor radon levels inside the Kufa Technical Institute buildings for the first time using different radon measurement methods such as active (RAD-7) and passive methods (LR-115 Type II). Seventy eight of Solid-State Nuclear Track Detectors (SSNTDs) LR-115 Type II was distributed at four buildings within the study area. The LR-115 Type II detectors were exposed in the study area for three months period. In parallel to the latter, seventy two active measurements were conducted using RAD-7 in the same buildings for correlation investigation purposes between the two kinds of measurements (i.e. passive and active).The results demonstrate that the radon concentrations were generally low, which are ranging from 38.4 to $77.2 \mathrm{~Bq} / \mathrm{m}^{3}$, with a mean value of $50 \mathrm{~Bq} / \mathrm{m}^{3}$. The mean of the equilibrium equivalent radon concentration and annual effective dose were assessed to be $19.9 \mathrm{~Bq} / \mathrm{m}^{3}$ and $1.2 \mathrm{mS} / \mathrm{y}$ respectively; the excess lifetime lung cancer risk was approximately 11.6 per million personal. A high correlation was found between the methods of measurements (i.e. LR-115 Type II and RAD-7), $\mathrm{R}^{2}=0.99$ which is significant at $\mathrm{P}<0.001$. The results of this work revealed that that Radon concentration was below the action level set by the United States Environmental Protection Agency of $148 \mathrm{~Bq} / \mathrm{m}^{3}$. This therefore indicates that no radiological health hazard exists. However, the relatively high concentrations in some classrooms can be addressed by the natural ventilation or the classrooms being supplied with suction fans.

Keywords: radon concentrations, excess of lung risk factor, Kufa Technical Institute buildings.

\section{Introduction}

Humans are exposed to radiation from different sources. An example of those sources is the naturally occurring radioactive materials (NORM) that exists in food, water and atmosphere. The biggest proportion of natural radiation comes from a radioactive gas which is known by radon whose its chemical symbol is ${ }^{222} \mathrm{Rn}$. However, the annual average effective dose of natural radiation that the human is exposed is established to be $2.4 \mathrm{mSv} / \mathrm{y}$. The radon contribution to this is estimated to be around $1.2 \mathrm{mSv} / \mathrm{y}$ [1]. The body exposure to ionizing radiation from the above sources may cause certain changes in the sensitive biological structures, either directly by transferring of the energy to the atoms of the tissue resulting in a chain of biological changes; this is known by direct action of radiation or by interacting with water molecules inside a cell to produce free radicals. The free radicals are able to diffuse over a distance to interact with the critical biological targets and then causing intercellular damages. The latter interaction is called indirect action of radiation [2].

Buildings are generally having low indoor air pressure compared with that of ground. This may, in turn, leads to some soil gas to leak from ground into the building. Radon gas can diffuse into a building by several ways, however the most common ways are through the diffusion and pressure that driven flow from the ground beneath and straight off adjacent to the building, providing an appropriate ingress routes. The route of ingress of radon can typically be described as holes and cracks in walls and floors, and gaps exist nearer to cables and pipes. In most dwellings with elevated indoor radon concentrations pressure-driven flow has been recognized as the dominant mechanism of entry [3]. The indoor radon is naturally originated from soil, building materials (rocks, sand, cement, etc.), and water born transport, natural energy sources such as gas and coal which include ${ }^{238} \mathrm{U}$ traces. The concentration of indoor radon depends mainly upon radon exhalation from surrounding materials [4]. In this context, radon gas is heavier than air, so it is not often a problem within the higher stories or high buildings [3]. Radon, $\mathrm{Rn}-222$ ( $\mathrm{T}_{1 / 2}=3.82$ days), is a daughter product of ${ }^{226} \mathrm{Ra}$, which is in turn derived from the longer-lived antecedent, ${ }^{238} \mathrm{U}$. Thoron, Rn$220\left(\mathrm{~T}_{1 / 2}=56 \mathrm{~s}\right)$ is a daughter of ${ }^{232} \mathrm{Th}$, which presents in a big percentage in the earth's crust than radon. Because of thoron's short half-life, it is essentially gone before it leaves the ground, and it of no significant radiobiologic consequences. 
The latter radionuclide series are existing in small proportion within the environment (geologic time scale). This owned to radioactive decay of their parents, which has been recognized and understood since the end of the last century [5]. There are many methods that can be used for radon measurements. These include solid-state nuclear track detectors (SSNTD) which are considered to be the most reliable technique for the determination of the radon concentration; LR-115 cellulose nitrate Type II thin films $\left(\mathrm{C}_{6} \mathrm{H}_{2} \mathrm{O}_{9} \mathrm{~N}_{2}\right)$ which is widely used as a radon concentration measurement device. In this detector, the color of track is seen as red and it is characterized by being insensitive to electrons and electromagnetic radiations [6]. Many previous studies have focused on measuring the concentrations of radon in buildings were identified [6 10]. The aim of this work is to measure the radon using SSNTD technique and estimation of excess in cancer due to increment in radon gas.

\section{The Area of Study}

The Technical Institute of Kufa was established in 1980 at a location of $\left(32^{\circ} 3^{\prime} 34^{\prime \prime} \mathrm{N}\right)$ latitude and $\left(44^{\circ} 24^{\prime} 18^{\prime \prime} \mathrm{E}\right)$ longitude with a total area of $268035 \mathrm{~m}^{2}$ [11] as seen in Fig. 1.

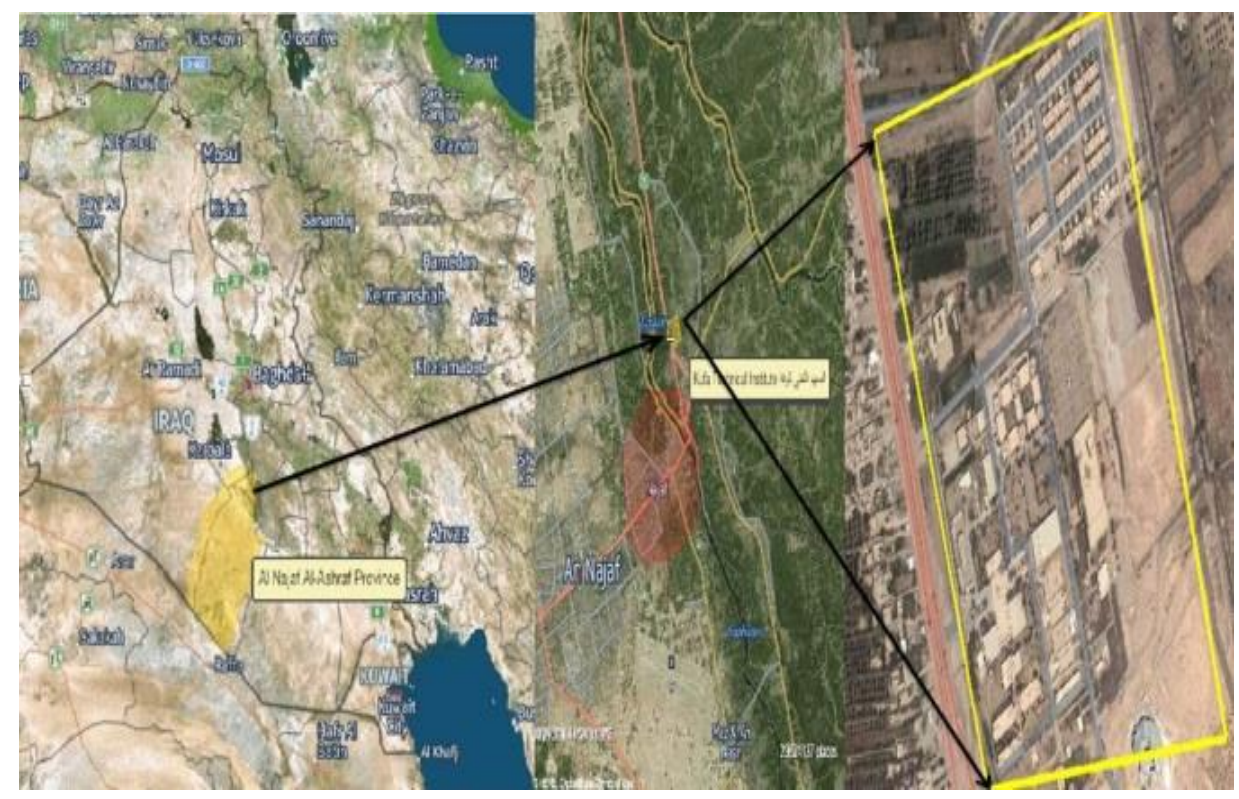

Fig. 1. Location of Kufa Technical Institute.

The Institute includes four health departments namely: pharmacology, pathological analyses and community health and nursing. It also includes three engineering departments; these are electricity, mechanics and automotive division (cars). In addition to these departments, it contains the administrative department and two departments of agriculture that are specialized in plant and animal production. The study area was chosen for a number of reasons. First, these buildings are easy to access and it is easy to deal with educated people that will reduce the losses in distributed detectors; second, it is easy to distribute and collect detectors in governmental buildings compared with other public places; finally, institutional buildings are highly populated with people who exposed to radon as they are spending long working time in the buildings. The dwelling of this Technical Institute was built using different materials. This includes cement, sand stones, bricks, iron structure, marble, and concrete. In this regards, building materials are another source of radiation exposure (external and internal) in both dwelling and public buildings [3]. The external is resulted from the emission of gamma rays from ${ }^{238} \mathrm{U}$ and ${ }^{232} \mathrm{Th}$ series as well as from ${ }^{40} \mathrm{~K}$ radionuclides. By contrast, the internal exposure is caused by the inhalation of radon gas together with their short lived decay products. In Iraq, many studies have been conducted to assess the radioactivity in building materials that have been used in construction of buildings of Kufa Technical Institute, Iraq. The results of specific activity of ${ }^{238} \mathrm{U}$, ${ }^{232} \mathrm{Th}$ and ${ }^{40} \mathrm{~K}$ of certain local building materials in the middle Euphrates of Iraq ranged between 32.9 (Najaf gypsum) to $179.32 \mathrm{~Bq} / \mathrm{kg}$ (Karbala cement), 1.98 (Najaf sand) to $17.43 \mathrm{~Bq} / \mathrm{kg}$ (Qadisiya brick) and 108.73 (Karbala sand) to $977.79 \mathrm{~Bq} / \mathrm{kg}$ (Najaf bricks) respectively [12]. Some of them contribute greatly to indoor radon emission. All buildings were occupied throughout this measurement. It should be noted that the studied buildings include a number of storey (i.e. 2 or 3 ) which equipped with a central air conditioning. Further to this, a considerable attention has been given to the ventilation system taken into 
account the governmental rules for constructing buildings aimed for residency. Nevertheless, it is worth mention that radon, as a noble gas, being heavier seven times than the air; therefore it is practically suitable to place the detector at the lower floor for good a measurement and for all buildings.

\section{Materials and Methods}

There are two different methods used to measure the radon concentration. First, a passive technique called solid state nuclear track detector (LR-115 Type II), and a continuous active radon sampling such as RAD-7 detector. Further details on these two techniques can be seen in the next sections.

\section{Measurement of Radon Using Passive Method (LR-115 Type II Detector)}

The radon dosimeter used in this work is made up of plastic cup $10.0 \mathrm{~cm}$ in diameter and $13 \mathrm{~cm}$ in depth, its cover includes a $0.5 \mathrm{~cm}$ hole sealed with a piece of sponge with an area of $1 \times 1 \mathrm{~cm}^{2}$ and $0.5 \mathrm{~cm}$ thickness, this configuration was necessary to ensures that the thoron cannot reach the detector. The plastic cup contains one LR-115 Type II, $12 \mu \mathrm{m}$ thick, cellulose nitrate based SSNTDs manufactured by Kodak Pathe, France with an area of $1 \times 1 \mathrm{~cm}^{2}$ fixed at the bottom by double-sided cello-tape. The region indicated in the right side of figure (1) was divided into 10 parts, in each part and according to the size of building, six to fourteen dosimeters were allocated. Specifically, the dosimeters were placed in a sitting room at a height about $(1-2) \mathrm{m}$ above the floor. The period of dosimeters' exposure was 90 days extended from $1 / 11 / 2014$ to $1 / 2 / 2015$; throughout this period, $\alpha$-particles emitted by the radon and their progeny which in turn bombard the SSNTD films. After the irradiation, the exposed films were etched in a $\mathrm{NaOH}$ solution with optimum conditions $\left(2.5 \mathrm{~N}\right.$ at $60^{\circ} \mathrm{C}$ for $2 \mathrm{hr}$, for LR-115 II films). After that, the track densities on the LR-115 Type II SSNTD were determined by an optical microscope. Each LR-115 Type II detector was scanned with five fields of views. The area of the field of view was calculated using laptop and RZ Camera application software. The software has three functions: video process function, image process function and image measure function. For each detector the number of tracks was averaged over all five fields of views. During this process care was taken to distinguish between the tracks and dust particles.

For dosimetry purposes, it is important to measure the average radon concentration over time which should be long enough relative to the typical time scale of radon fluctuations caused by environmental conditions. The measured signal of the etched track detectors is the integrated track density as follows:

$$
\begin{gathered}
\text { Track density }\left(\rho\left(\text { track } / \mathrm{cm}^{2}\right)=\right. \\
=\frac{\text { Average number of total pits (tracks) }}{\text { Area of field view }},
\end{gathered}
$$

where $\rho$ is recorded on the detector, track $/ \mathrm{cm}^{2} ; \mathrm{C}_{\mathrm{Rn}}$ is the ${ }^{222} \mathrm{Rn}$ concentration, $\mathrm{Bq} / \mathrm{m}^{3}$, which was determined using the following Eqs. (i.e. 2, 3 and 4) [13]:

$$
\begin{gathered}
C\left(\mathrm{~Bq} \cdot \mathrm{m}^{-3}\right)=K\left\{\frac{\rho\left(\text { track } \cdot \mathrm{cm}^{-2}\right)}{t(\text { day })}\right\}_{\mathrm{det}}, \\
\sigma_{n}(\text { S.D. })=\sqrt{\frac{\sum_{i}^{n}\left(X_{i}-\bar{X}\right)^{2}}{n-1}},
\end{gathered}
$$

where $C$ is ${ }^{222} \mathrm{Rn}$ concentration within the seals-cup air above the detector, $\mathrm{Bq} / \mathrm{m}^{3} ; C_{o}$ is the activity of standard sample, $\mathrm{Bq} \cdot$ day $\cdot \mathrm{m}^{-3} ; \rho_{\mathrm{o}}$ is track density, number of track $\cdot \mathrm{cm}^{-2}$, on the detector, exposed to standard source; $\rho$ is track density, number of track $\cdot \mathrm{cm}^{-2}$, of the detectors exposed to the samples under study; $t$ is exposure time, days, and $\sigma_{n}(S . D$.$) is$ the standard deviation; $K$ is the average value of the calibration factor of ${ }^{222} \mathrm{Rn} . \mathrm{Bq} /\left(\mathrm{m}^{3}\right.$. day $)$ per tracks $\cdot \mathrm{cm}^{2}$, and $t$ exposure time, day. $K$ can be obtained using Eq. (4)

$$
k=\frac{C_{o}\left(\mathrm{~Bq} \cdot \mathrm{day} \cdot \mathrm{m}^{-3}\right)}{\rho\left(\operatorname{track} \cdot \mathrm{cm}^{-2}\right)} .
$$

The calibration factor was obtained by exposing reference dosimeters for a period of time ranged from 5 - 30 days to ${ }^{226} \mathrm{Ra}$ (Radon source) which activity is $3.3 \mathrm{kBq}$ which was found to be $0.0217 \pm 0.0013$ track $\cdot \mathrm{cm}^{-2}$ per $\mathrm{Bq} \cdot$ day $\cdot \mathrm{m}^{-3}$. The latter value is approximately similar to that reported in many previous works [14 - 17]. The resulting concentration of short-lived radon daughters expressed in term of an equilibrium-equivalent radon concentration (EEC), that is related to the activity concentration of radon (C) by the Eq. (5) [18]:

$$
E E C=C \cdot F,
$$

where $F$ is an equilibrium factor which is equal 0.4 in indoor air. Now the Eq. (6) was used to calculate the annual absorbed dose and effective dose rate received by the population, according to the UNSCEAR (2000) report [19], in this regard the 
committee proposed $9 \cdot 10^{-6} \mathrm{mSv} \cdot \mathrm{m}^{3} / \mathrm{h} \cdot \mathrm{Bq}$ to be used as conversion factor [20]:

$$
D_{R n}=C \cdot D \cdot H \cdot F \cdot T,
$$

where $D_{R n}$ is the annual absorbed dose, $\mathrm{mSv} / \mathrm{y} ; C$ is the indoor radon concentration; $D$ is the dose conversion factor which is equal $9 \cdot 10^{-6} \mathrm{mSv} / \mathrm{m}^{3} / \mathrm{h} \times$ $\times \mathrm{Bq} ; H$ is the indoor occupancy factor which is equal 0.4 ; and $T$ is the indoor occupancy time which is equal $24 \mathrm{hr} \cdot 365=8760 \mathrm{hr} / \mathrm{yr}$.

The annual effective dose $H_{E}$ was calculated according to the Eq. (7) [20]:

$$
H_{E}=D_{R n} \cdot W_{R} \cdot W_{T},
$$

where $W_{R}$ and $W_{T}$ are the radiation weighting factor and tissue weighting factor respectively according to ICRP, $\left(W_{R}=20\right)$ and $\left(W_{T}=0.12\right)$.

Excess Lifetime Cancer Risk (ELCR) calculation is also considered in this study. This can be defined as potential carcinogenic effects that estimate the probability of incidence of cancer in a population of individuals for a specific lifetime from exposures and dose-response data (i.e., slope factors). This is achieved by multiplying the intake by the slope factor. Then, the ELCR result is a matter of a probability. The extra risk of developing cancer owing to exposure to a toxic substance incurred across the lifetime of an individual. Overall, the ELCR deals with the probability of developing cancer over a lifetime at a given exposure.
The ELCR per million persons per year (MPY) was calculated using formula in Ref. [21]:

$$
E L C R=H_{E} \cdot D L \cdot R F,
$$

where $D L$ is the duration of life (70 yr) and RF is the risk factor $\left(0.055 \mathrm{~Sv}^{-1}\right)$ recommended by the ICRP [21].

\section{Measurement of Radon Using an Active Method (RAD-7) Detector}

In this study, six buildings were tested for measuring radon concentration using RAD-7 technique taken from some locations of certain buildings which were already tested by LR-115 Type II detector. Sniff phase and circulation time were set to be for one day in accordance with running time of each path of the valve. For the purpose of investigating the amount of radon released from the sample to air, the sample was placed in a closed cylinder which allows airborne radon to be measured with a continuous monitor of electrostatic type (RAD-7, Durridge company, USA) [22].

\section{Results and Discussions}

The resulted data from LR-115 Type II measurements of the 14 buildings in Kufa Technical Institute are presented in 14 Tables (from Table 1 to Table 14). Each Table includes the minimum, maximum and average of concentration of radon. Also it includes information about the dosimeters sample No and sample code.

Table 1. Observed indoor radon concentrations in school

\begin{tabular}{|c|c|c|c|c|}
\hline \multirow{2}{*}{ No. } & \multirow{2}{*}{ Sample Code } & \multicolumn{3}{|c|}{ Radon concentrations, Bq/m } \\
\cline { 3 - 5 } & & Minimum & Maximum & Average \pm S.D \\
\hline 1 & S1 & 48.7 & 63.7 & $58.0 \pm 6.4$ \\
\hline 2 & S2 & 46.2 & 59.6 & $55.1 \pm 6.2$ \\
\hline 3 & S3 & 50.0 & 83.3 & $62.6 \pm 15.5$ \\
\hline 4 & S4 & 53.1 & 87.1 & $64.5 \pm 15.4$ \\
\hline 5 & S5 & 47.3 & 85.7 & $62.6 \pm 16.8$ \\
\hline & Average & $\mathbf{4 9 . 1} \pm \mathbf{2 . 6}$ & $\mathbf{7 5 . 9} \pm \mathbf{1 3 . 1}$ & $\mathbf{6 0 . 6} \pm \mathbf{3 . 8}$ \\
\hline
\end{tabular}

Table 2. Observed indoor radon concentrations in Student Housing

\begin{tabular}{|c|c|c|c|c|}
\hline \multirow{2}{*}{ No. } & \multirow{2}{*}{ Sample Code } & \multicolumn{3}{|c|}{ Radon concentrations, Bq $/ \mathrm{m}^{3}$} \\
\cline { 3 - 5 } & & Minimum & Maximum & Average \pm S.D \\
\hline 1 & SHM1 & 52.6 & 62.0 & $56.1 \pm 4.1$ \\
\hline 2 & SHM2 & 48.0 & 62.8 & $54.8 \pm 7.8$ \\
\hline 3 & SHM3 & 43.5 & 62.2 & $52.0 \pm 7.7$ \\
\hline 4 & SHM4 & 49.4 & 63.4 & $55.8 \pm 6.0$ \\
\hline 5 & SHM5 & 39.3 & 61.3 & $51.0 \pm 9.0$ \\
\hline \multicolumn{2}{|c|}{ Average } & $\mathbf{4 6 . 6} \pm \mathbf{5 . 2}$ & $\mathbf{6 2 . 3} \pm \mathbf{0 . 8}$ & $\mathbf{5 3 . 9} \pm \mathbf{2 . 3}$ \\
\hline
\end{tabular}


Table 3. Observed indoor radon concentrations in Agricultural Department

\begin{tabular}{|c|c|c|c|c|}
\hline \multirow{2}{*}{ No. } & \multirow{2}{*}{ Sample Code } & \multicolumn{3}{|c|}{ Radon concentrations, Bq/m } \\
\cline { 3 - 5 } & & Minimum & Maximum & Average \pm S.D \\
\hline 1 & AG1 & 49.5 & 86.6 & $64.6 \pm 18.0$ \\
\hline 2 & AG2 & 35.3 & 56.5 & $43.1 \pm 9.5$ \\
\hline 3 & AG3 & 53.3 & 77.0 & $63.4 \pm 11.0$ \\
\hline 4 & AG4 & 35.5 & 50.0 & $42.7 \pm 6.8$ \\
\hline \multicolumn{2}{|c|}{ Average } & $\mathbf{4 3 . 4} \pm \mathbf{9 . 3}$ & $\mathbf{6 7 . 5} \pm \mathbf{1 7 . 1}$ & $\mathbf{5 3 . 5} \pm \mathbf{1 2 . 1}$ \\
\hline
\end{tabular}

Table 4. Observed indoor radon concentrations in Nursing Department

\begin{tabular}{|c|c|c|c|c|}
\hline \multirow{2}{*}{ No. } & \multirow{2}{*}{ Sample Code } & \multicolumn{3}{|c|}{ Radon concentrations, Bq/m } \\
\cline { 3 - 5 } & & Minimum & Maximum & Average \pm S.D \\
\hline 1 & N1 & 24.3 & 32.3 & $27.5 \pm 3.5$ \\
\hline 2 & N2 & 35.6 & 58.9 & $42.8 \pm 10.9$ \\
\hline 3 & N3 & 52.9 & 65.7 & $62.3 \pm 6.2$ \\
\hline 4 & N4 & 20.2 & 34.2 & $28.6 \pm 6.5$ \\
\hline 5 & N5 & 34.9 & 49.8 & $42.6 \pm 6.8$ \\
\hline \multicolumn{2}{|c|}{ Average } & $\mathbf{3 3 . 6} \pm \mathbf{1 2 . 7}$ & $\mathbf{4 8 . 2} \pm \mathbf{1 4 . 7}$ & $\mathbf{4 0 . 8} \pm \mathbf{1 4 . 1}$ \\
\hline
\end{tabular}

Table 5. Observed indoor radon concentrations in Computer Center

\begin{tabular}{|c|c|c|c|c|}
\hline \multirow{2}{*}{ No. } & \multirow{2}{*}{ Sample Code } & \multicolumn{3}{|c|}{ Radon concentrations. Bq $/ \mathrm{m}^{3}$} \\
\cline { 3 - 5 } & & Minimum & Maximum & Average \pm S.D \\
\hline 1 & C1 & 48.8 & 62.3 & $54.3 \pm 6.5$ \\
\hline 2 & C2 & 52.0 & 57.8 & $55.4 \pm 2.6$ \\
\hline 3 & C3 & 50.5 & 58.3 & $55.8 \pm 3.6$ \\
\hline 4 & C4 & 44.3 & 62.3 & $54.9 \pm 7.9$ \\
\hline 5 & C5 & 48.5 & 60.8 & $56.7 \pm 5.6$ \\
\hline 6 & C6 & 57.3 & 85.5 & $64.4 \pm 14.0$ \\
\hline \multicolumn{2}{|c|}{ Average } & $\mathbf{5 0 . 2} \pm \mathbf{4 . 3}$ & $\mathbf{6 4 . 5} \pm \mathbf{1 0 . 4}$ & $\mathbf{5 6 . 9} \pm \mathbf{3 . 7}$ \\
\hline
\end{tabular}

Table 6. Observed indoor radon concentrations in Administrative Department

\begin{tabular}{|c|c|c|c|c|}
\hline \multirow{2}{*}{ No. } & \multirow{2}{*}{ Sample Code } & \multicolumn{3}{|c|}{ Radon concentrations, Bq $/ \mathrm{m}^{3}$} \\
\cline { 3 - 5 } & & Minimum & Maximum & Average \pm S.D \\
\hline 1 & AD1 & 33.1 & 65.2 & $48.7 \pm 15.7$ \\
\hline 2 & AD2 & 21.5 & 32.8 & $29.3 \pm 5.3$ \\
\hline 3 & AD3 & 29.9 & 43.9 & $35.7 \pm 5.8$ \\
\hline 4 & AD4 & 23.7 & 68.0 & $39.8 \pm 19.5$ \\
\hline \multicolumn{2}{|r}{ Average } & $\mathbf{2 7 . 0} \pm \mathbf{5 . 3}$ & $\mathbf{5 2 . 5} \pm \mathbf{1 6 . 9}$ & $\mathbf{3 8 . 4} \pm \mathbf{8 . 1}$ \\
\hline
\end{tabular}

Table 7. Observed indoor radon concentrations in Institute Deanship

\begin{tabular}{|c|c|c|c|c|}
\hline \multirow{2}{*}{ No. } & \multirow{2}{*}{ Sample Code } & \multicolumn{3}{|c|}{ Radon Concentrations, $\mathrm{Bq} / \mathrm{m}^{3}$} \\
\hline & & Minimum & Maximum & Average \pm S.D \\
\hline 1 & ID1 & 29.1 & 55.7 & $43.4 \pm 11.7$ \\
\hline 2 & ID2 & 33.1 & 60.0 & $46.1 \pm 11.1$ \\
\hline 3 & ID3 & 31.2 & 50.2 & $40.9 \pm 7.7$ \\
\hline 4 & ID4 & 42.5 & 73.3 & $56.2 \pm 12.7$ \\
\hline 5 & ID5 & 37.9 & 49.5 & $41.7 \pm 5.3$ \\
\hline 6 & ID6 & 14.8 & 69.0 & $34.5 \pm 24.5$ \\
\hline 7 & ID7 & 18.4 & 47.1 & $34.4 \pm 14.3$ \\
\hline 8 & ID8 & 35.5 & 51.0 & $43.5 \pm 6.8$ \\
\hline 9 & ID9 & 51.8 & 66.9 & $56.9 \pm 6.9$ \\
\hline 10 & ID10 & 27.2 & 79.1 & $60.4 \pm 23.5$ \\
\hline 11 & ID11 & 34.5 & 40.5 & $37.5 \pm 3.3$ \\
\hline 12 & ID12 & 30.1 & 39.8 & $33.7 \pm 4.4$ \\
\hline 13 & ID13 & 22.0 & 83.0 & $49.4 \pm 25.7$ \\
\hline 14 & ID14 & 49.3 & 60.9 & $53.9 \pm 5.2$ \\
\hline \multicolumn{2}{|c|}{ Average } & $32.7 \pm 10.6$ & $59.0 \pm 13.7$ & $45.2 \pm 8.9$ \\
\hline
\end{tabular}


Table 8. Observed indoor radon concentrations in Pharmacy Department

\begin{tabular}{|c|c|c|c|c|}
\hline \multirow{2}{*}{ No. } & \multirow{2}{*}{ Sample Code } & \multicolumn{3}{|c|}{ Radon Concentrations, Bq/m } \\
\cline { 3 - 5 } & & Minimum & Maximum & Average \pm S.D \\
\hline 1 & P1 & 36.4 & 41.6 & $38.7 \pm 2.1$ \\
\hline 2 & P2 & 44.9 & 62.1 & $54.0 \pm 7.1$ \\
\hline 3 & P3 & 38.5 & 41.8 & $40.3 \pm 1.6$ \\
\hline 4 & P4 & 47.7 & 59.8 & $56.0 \pm 5.5$ \\
\hline 5 & P5 & 31.2 & 42.2 & $36.2 \pm 4.6$ \\
\hline 6 & P6 & 39.0 & 55.3 & $47.0 \pm 7.2$ \\
\hline \multicolumn{7}{r}{ Average } & $\mathbf{3 9 . 6} \pm \mathbf{5 . 9}$ & $\mathbf{5 0 . 5} \pm \mathbf{9 . 6}$ & $\mathbf{4 5 . 4} \pm \mathbf{8 . 2}$ \\
\hline
\end{tabular}

Table 9. Observed indoor radon concentrations in Health and Analyses Departments

\begin{tabular}{|c|c|c|c|c|}
\hline \multirow{2}{*}{ No. } & \multirow{2}{*}{ Sample Code } & \multicolumn{3}{|c|}{ Radon Concentrations, $\mathrm{Bq} / \mathrm{m}^{3}$} \\
\hline & & Minimum & Maximum & Average \pm S.D \\
\hline 1 & HA1 & 47.0 & 96.7 & $68.6 \pm 21.6$ \\
\hline 2 & HA2 & 34.9 & 55.7 & $44.6 \pm 9.5$ \\
\hline 3 & HA3 & 36.1 & 58.8 & $46.1 \pm 11.2$ \\
\hline 4 & HA4 & 36.5 & 56.4 & $45.8 \pm 10.5$ \\
\hline 5 & HA5 & 30.1 & 69.4 & $43.9 \pm 17.8$ \\
\hline 6 & HA6 & 39.6 & 60.2 & $45.6 \pm 9.7$ \\
\hline 7 & HA7 & 37.1 & 56.6 & $46.4 \pm 8.0$ \\
\hline 8 & HA8 & 38.8 & 46.5 & $43.0 \pm 3.2$ \\
\hline 9 & HA9 & 41.5 & 54.6 & $46.4 \pm 5.7$ \\
\hline 10 & HA10 & 41.8 & 53.4 & $45.6 \pm 5.3$ \\
\hline 11 & HA11 & 39.1 & 58.8 & $45.2 \pm 9.1$ \\
\hline 12 & HA12 & 41.1 & 50.0 & $44.7 \pm 3.8$ \\
\hline \multicolumn{2}{|c|}{ Average } & $38.6 \pm 4.2$ & $59.8 \pm 12.9$ & $47.2 \pm 6.8$ \\
\hline
\end{tabular}

Table 10. Observed indoor radon concentrations in Electric Department

\begin{tabular}{|c|c|c|c|c|}
\hline \multirow{2}{*}{ No. } & \multirow{2}{*}{ Sample Code } & \multicolumn{3}{|c|}{ Radon Concentrations, $\mathrm{Bq} / \mathrm{m}^{3}$} \\
\hline & & Minimum & Maximum & Average \pm S.D \\
\hline 1 & E1 & 21.1 & 53.4 & $41.4 \pm 15.1$ \\
\hline 2 & E2 & 24.9 & 38.5 & $29.5 \pm 6.0$ \\
\hline 3 & E3 & 26.0 & 46.3 & $31.6 \pm 9.8$ \\
\hline 4 & E4 & 29.2 & 63.3 & $46.6 \pm 14.1$ \\
\hline 5 & E5 & 27.3 & 41.1 & $33.4 \pm 6.2$ \\
\hline 6 & E6 & 31.9 & 50.1 & $43.5 \pm 9.3$ \\
\hline 7 & E7 & 40.4 & 61.1 & $50.1 \pm 10.7$ \\
\hline 8 & E8 & 28.0 & 40.1 & $33.4 \pm 5.0$ \\
\hline \multicolumn{2}{|c|}{ Average } & $28.6 \pm 5.7$ & $49.2 \pm 9.8$ & $38.7 \pm 7.6$ \\
\hline
\end{tabular}

Table 11. Observed indoor radon concentrations in Workshops

\begin{tabular}{|c|c|c|c|c|}
\hline \multirow{2}{*}{ No. } & \multirow{2}{*}{ Sample Code } & \multicolumn{3}{|c|}{ Radon Concentrations, Bq/m } \\
\cline { 3 - 5 } & & Minimum & Maximum & Average \pm S.D \\
\hline 1 & W1 & 76.3 & 89.1 & $82.7 \pm 6.7$ \\
\hline 2 & W2 & 60.8 & 87.3 & $71.6 \pm 11.3$ \\
\hline 3 & W3 & 67.6 & 91.3 & $74.5 \pm 11.2$ \\
\hline 4 & W4 & 68.3 & 92.6 & $79.9 \pm 12.8$ \\
\hline \multicolumn{2}{|c|}{ Average } & $\mathbf{6 8 . 3} \pm \mathbf{6 . 3}$ & $\mathbf{9 0 . 1} \pm \mathbf{2 . 3}$ & $\mathbf{7 7 . 2} \pm \mathbf{5 . 0}$ \\
\hline
\end{tabular}


Table 12. Observed indoor radon concentrations in Mechanics Department

\begin{tabular}{|c|c|c|c|c|}
\hline \multirow{2}{*}{ No. } & \multirow{2}{*}{ Sample Code } & \multicolumn{3}{|c|}{ Radon Concentrations, Bq $/ \mathrm{m}^{3}$} \\
\cline { 3 - 5 } & & Minimum & Maximum & Average \pm S.D \\
\hline 1 & M1 & 50.6 & 60.5 & $55.6 \pm 4.8$ \\
\hline 2 & M2 & 29.2 & 48.1 & $37.0 \pm 8.6$ \\
\hline 3 & M3 & 47.1 & 54.8 & $51.8 \pm 3.2$ \\
\hline 4 & M4 & 43.3 & 56.4 & $48.1 \pm 5.9$ \\
\hline 5 & M5 & 37.4 & 69.6 & $49.7 \pm 13.9$ \\
\hline 6 & M6 & 28.7 & 51.2 & $41.8 \pm 9.7$ \\
\hline \multicolumn{2}{|c|}{ Average } & $\mathbf{3 9 . 4} \pm \mathbf{9 . 2}$ & $\mathbf{5 6 . 8} \pm \mathbf{7 . 5}$ & $\mathbf{4 7 . 3} \pm \mathbf{6 . 7}$ \\
\hline
\end{tabular}

Table 13. Observed indoor radon concentrations in Cars Department

\begin{tabular}{|c|c|c|c|c|}
\hline \multirow{2}{*}{ No. } & \multirow{2}{*}{ Sample Code } & \multicolumn{3}{|c|}{ Radon Concentrations, $\mathrm{Bq} / \mathrm{m}^{3}$} \\
\cline { 3 - 5 } & & Minimum & Maximum & Average \pm S.D \\
\hline 1 & CD1 & 51.6 & 62.4 & $57.1 \pm 4.8$ \\
\hline 2 & CD2 & 34.9 & 56.8 & $45.5 \pm 8.9$ \\
\hline 3 & CD3 & 53.6 & 63.6 & $58.9 \pm 5.0$ \\
\hline 4 & CD4 & 39.2 & 57.5 & $50.5 \pm 8.4$ \\
\hline 5 & CD5 & 36.5 & 57.8 & $47.0 \pm 10.4$ \\
\hline 6 & CD6 & 47.8 & 59.1 & $53.3 \pm 6.1$ \\
\hline \multicolumn{2}{|l}{ Average } & $\mathbf{4 3 . 9} \pm \mathbf{8 . 0}$ & $\mathbf{5 9 . 5} \pm \mathbf{2 . 7}$ & $\mathbf{5 2 . 0} \pm \mathbf{5 . 3}$ \\
\hline
\end{tabular}

Table 14. Observed indoor radon concentrations in Healthy Technical Deanship

\begin{tabular}{|c|c|c|c|c|}
\hline \multirow{2}{*}{ No. } & \multirow{2}{*}{ Sample Code } & \multicolumn{3}{|c|}{ Radon Concentrations, Bq $/ \mathrm{m}^{3}$} \\
\cline { 3 - 5 } & & Minimum & Maximum & Average \pm S.D \\
\hline 1 & HD1 & 27.1 & 36.5 & $31.7 \pm 3.8$ \\
\hline 2 & HD2 & 37.9 & 53.6 & $46.4 \pm 8.6$ \\
\hline 3 & HD3 & 34.4 & 48.9 & $41.8 \pm 7.4$ \\
\hline 4 & HD4 & 29.2 & 34.8 & $31.7 \pm 2.5$ \\
\hline 5 & HD5 & 33.9 & 53.0 & $38.9 \pm 9.3$ \\
\hline 6 & HD6 & 30.0 & 42.8 & $38.4 \pm 5.8$ \\
\hline 7 & HD7 & 21.0 & 43.9 & $30.8 \pm 9.5$ \\
\hline 8 & HD8 & 45.3 & 63.7 & $55.4 \pm 7.5$ \\
\hline 9 & HD9 & 21.7 & 70.8 & $50.6 \pm 23.6$ \\
\hline 10 & HD10 & 37.4 & 62.4 & $52.4 \pm 10.8$ \\
\hline \multicolumn{2}{|r}{ Average } & $\mathbf{3 1 . 8} \pm \mathbf{7 . 5}$ & $\mathbf{5 1 . 0} \pm \mathbf{1 1 . 9}$ & $\mathbf{4 1 . 8} \pm \mathbf{9 . 0}$ \\
\hline
\end{tabular}

The results obtained from the 94 LR-115 Type II detectors demonstrated that the radon concentration in a fourteen buildings of Kufa Technical Institute, Iraq varied from (38.4) to (77.2) with an average of (50) $\mathrm{Bq} / \mathrm{m}^{3}$, this finding can still be considered within normal limits and below the action level of buildings set by the international environment organizations which is $148 \mathrm{~Bq} / \mathrm{m}^{3}$ [23]. The average radon concentration obtained in this study was compared with other similar studies in literature that can be seen in references [24 - 28]. The difference between our study and those mentioned in literature are attributed to the variations in the factors that determine indoor radon concentrations such as the building material, ventilation rate and most importantly is the geology factor. In fact, this study can be considered as the first attempt to evaluate the risk that is related to radon existence in buildings of
Kufa Technical Institute, Iraq. The total number of locations measured should be extended in the future.

Table 15 shows the relation between the average value of the ${ }^{222} \mathrm{Rn}$ EEC, the annual effective dose equivalent (AEDE) and ELCR per million persons per year for buildings under study with building code.

From Table 15, the range of the average equilibrium equivalent ${ }^{222} \mathrm{Rn}$ were found to be $(15.3$ - 30.8) $\mathrm{Bq} / \mathrm{m}^{3}$, while the range of the average of the annual effective dose were found to be (0.9 1.9) $\mathrm{mSv} / \mathrm{y}$. Additionally, and according to our estimations, the Excess Lung Cancer in all buildings of Kufa Technical Institute, Iraq was found to range from (8.9 to 18.0) with an average value of 11.6 per million persons. The maximum value of annual effective dose was $1.9 \mathrm{mSv} / \mathrm{y}$, this value is indeed low when compared to the global limit 
Table 15. Observed Average of EEC, AEDE and ELCR duo to indoor radon concentrations in Buildings under Study

\begin{tabular}{|c|c|c|c|c|}
\hline No. & Building of Code & $\mathrm{EEC}, \mathrm{Bq} / \mathrm{m}^{3}$ & AEDE, mSv/y & ELCR \\
\hline 1 & $\mathrm{~S}$ & 24.2 & 1.5 & 14.1 \\
\hline 2 & $\mathrm{SH}$ & 21.5 & 1.3 & 12.5 \\
\hline 3 & $\mathrm{AG}$ & 21.4 & 1.3 & 12.4 \\
\hline 4 & $\mathrm{~N}$ & 16.3 & 1.0 & 9.5 \\
\hline 5 & $\mathrm{C}$ & 22.7 & 1.4 & 13.2 \\
\hline 6 & $\mathrm{AD}$ & 15.3 & 0.9 & 8.9 \\
\hline 7 & ID & 18.0 & 1.1 & 10.5 \\
\hline 8 & $\mathrm{P}$ & 18.1 & 1.1 & 10.5 \\
\hline 9 & HA & 18.8 & 1.1 & 11.0 \\
\hline 10 & $\mathrm{E}$ & 15.4 & 0.9 & 9.0 \\
\hline 11 & $\mathrm{~W}$ & 30.8 & 1.9 & 18.0 \\
\hline 12 & $\mathrm{M}$ & 18.9 & 1.1 & 11.0 \\
\hline 13 & $\mathrm{CD}$ & 20.8 & 1.3 & 12.1 \\
\hline 14 & HD & 16.7 & 1.0 & 9.7 \\
\hline \multicolumn{2}{|c|}{ Average } & $19.9 \pm 3.8$ & $1.2 \pm 0.2$ & $11.6 \pm 2.1$ \\
\hline
\end{tabular}

(i.e. range 1 - 3) $\mathrm{mSv} / \mathrm{y}$ [19]. We believe that this low value of the effective dose is related to low value of radon concentrations occupancy rate, while the average percentage value of the Excess Lung Cancer in all buildings of Kufa Technical Institute, Iraq was about 11.6 per million persons, associated to a chronic exposure to indoor radon. As the risk of lung cancer increases with increasing radon exposure, the preferred measure of this risk is the long-term average radon level. By way of comparison, the average values of ELCR results of the current study found to be lower than those in Kerbala which is 12.3 [29] (i.e. other Iraqi city $80 \mathrm{~km}$ north-west to the studied area) and of Kurdistan at 19.4 [31] (500 km north to the studied area). However, the current ELCR findings were higher than those reported in Baghdad at 1.7
(150 km north-east to the studied area) [31]. Fig. 2 compares between the average radon concentrations in six buildings of studied area using LR-115 Type II and RAD-7 detector. As can be seen from the data plotted in Fig. 3, a high linear correlation $\left(R^{2}=0.99\right)$ between long term passive detectors using LR-115 Type II and short term active detector using RAD-7 for indoor radon concentration measurements. The slope of the linear trend between long and short measurements is 1.02. For LR-115 Type II the measurements were conducted in around 3 months, and for RAD-7 the measurement was conducted for around $24 \mathrm{hr}$. This may indicate that the radon concentrations in case of buildings can be estimated using either long-term measurements of the LR-115 Type II or using short term measurements of the RAD-7 technique.

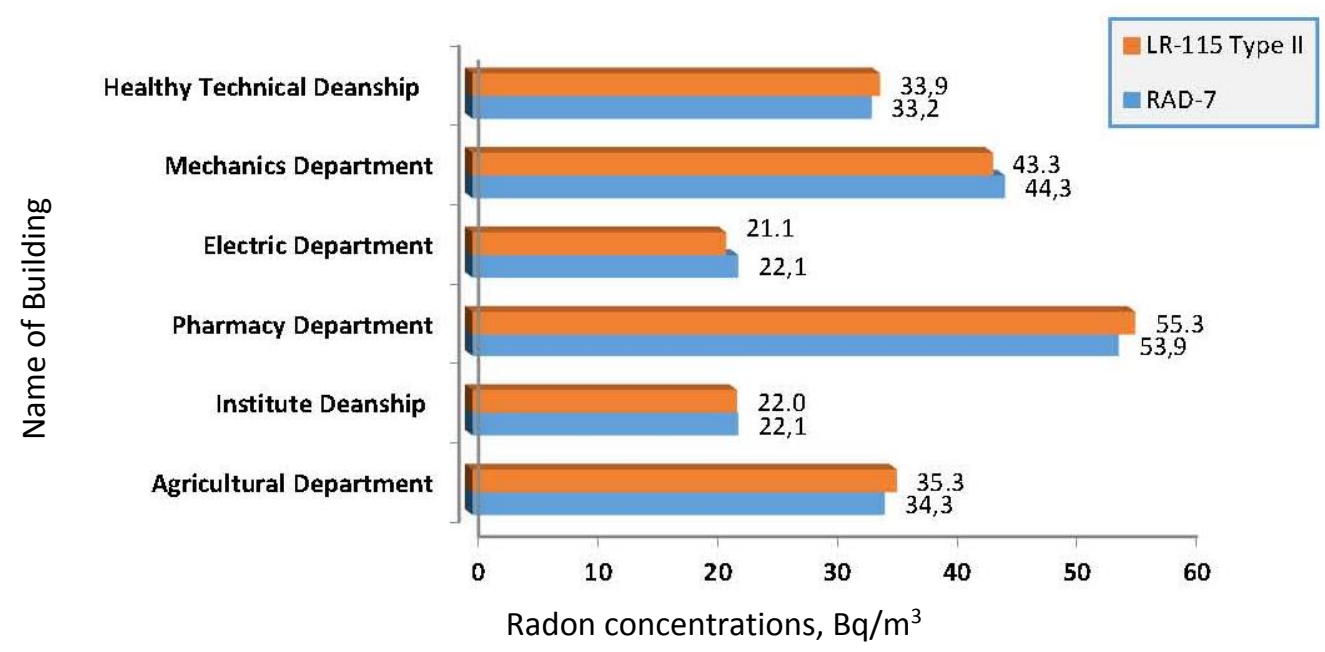

Fig. 2. Comparison of RAD-7 and LR-115 Type II results.

(See color Figure on the journal website.) 


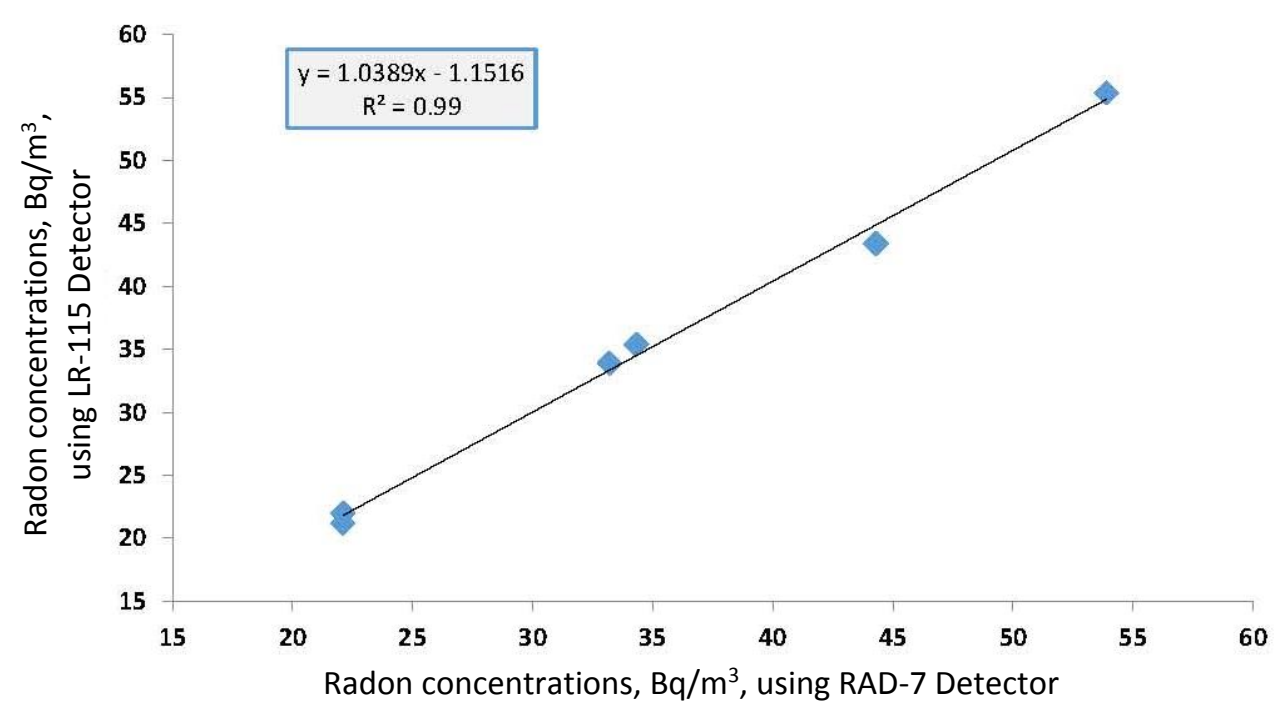

Fig. 3. Correlation between LR-115 Type II and RAD-7 measurements of indoor radon concentration.

\section{Conclusions}

Indoor radon concentration and excess relative risk of cancer were estimated for the residents of district Buildings of Kufa Technical Institute, Iraq. The measured indoor radon concentrations and calculated annual effective dose are found to be within acceptable ranges, according to the US EPA $\left(148 \mathrm{~Bq} / \mathrm{m}^{3}\right)$ and UNSCEAR $(1-3 \mathrm{mSv} / \mathrm{y})$. Also, it is found that the buildings in district are characterized by low radon, so the people who live in those buildings are subject to relatively low risk factor of radon induced cancer. Finally, all the buildings investigated are within the safe limits of radon exposure.

\section{REFERENCES}

1. Mohammed Kassim. Method development and determination of radon activity concentration in water using gamma spectrometry technique. MSc Thesis (University Technology Mara, 2012).

2. Wei Han, K.N. Yu. Ionizing radiation, DNA double strand break and mutation. In: Advances in Genetics Research. Vol. 4. Ed. V. Kevin Urbano (Nova Science Publishers, Inc., 2010).

3. Radon in existing building. Corrective options (Dublin: Brunswick Press Ltd., 2002) 30 p.

4. A.B. Ammar et al. Indoor radon concentration measurement in selected factories in Northern and Central Iraq. Journal of Environment and Earth Science 3(3) (2013) 105.

5. S.A. Rahimi, B. Nikpour. Measurement of Radon Concentration of Air Samples and Estimating Radiation Dose from Radon in SARI Province. Universal Journal of Public Health 1-2 (2013) 26.

6. I.V. Yarmoshenko, G.P. Malinovsky. Lung cancer mortality and radon exposure in Russia. Nukleonika 61(3) (2016) 263.

7. Deepak Verma, M.S. Khan. Assessment of indoor radon, thoron their progeny in dwelling of Bareilly city of Northern India using track etch detectors. Rom. Journ. Phys. 59(1-2) (2014) 172.

8. Mamta Gupta, A.K. Mahur, K.D. Verma. Indoor radon levels in some dwellings surrounding the National Thermal Power Corporations (NTPCs), India. Advances in Applied Science Research 3(3) (2012) 1262.

9. Mohamed Abd-Elzaher. An overview on studying
${ }^{222} \mathrm{Rn}$ exhalation rates using passive technique solidstate nuclear track detectors. American Journal of Applied Sciences 9(10) (2012) 1653.

10. Prabhjot Singha et al. A study of indoor radon, thoron and their progeny measurement in Tosham region Haryana, India. Journal of Radiation Research and Applied Sciences 8(2) (2015) 226.

11. Ali Abid Abojassim Al-Hamidawi. Monitoring of ${ }^{220} \mathrm{Rn}$ concentrations in buildings of Kufa Technical Institute, Iraq. Science and Technology of Nuclear Installations 2015 (2015) 738019.

12. H.H. Hussain et al. Natural radioactivity of some local building materials in the middle Euphrates of Iraq. Journal of Radioanalytic and Nuclear Chemistry 284 (2010) 43.

13. Ali Abid Abojassim et al. Radiological parameters due to radon-222 in soil samples at Baghdad Governorate (Karakh), Iraq. Pak. J. Sci. Ind. Res. Ser. A: Phys. Sci. 60(2) (2017) 72.

14. K.P. Eappen, Y.S. Mayya. Calibration factors for LR-115 (Type-II) based radon thoron discriminating dosimeter. Radiation Measurements 38 (2004) 5.

15. A.A. Abojassim et al. The effective radium content and radon exhalation rate in hair dyes samples. International Journal of Radiation Research 15(2) (2017) 207.

16. H.N. Hady, A.A. Abojassim, Z.B. Mohammed. Study of radon levels in fruits samples using LR-115 Type II detector. J. Environ. Sci. Technol. 9(6) (2016) 446.

17. Vikas Duggal, Asha Rani, Rohit Mehra. A study of 
seasonal variations of radon levels in different types of dwellings in Sri Ganganagar district, Rajasthan. Journal of Radiation Research and Applied Sciences 7 (2014) 201.

18. M.S.A. Khan, M. Tariq, R.B.S. Rawat. Preliminary measurements of radon radiations in "Bare Mode" in Rampur district of Western U.P. (India). IOSR Journal of Applied Physics 1(4) (2012) 4.

19. United Nations. Sources and Effects of Ionizing Radiation. United Nations Scientific Committee on the Effects of Atomic Radiation. UNSCEAR 2000 Report to the General Assembly, with annexes (New York: United Nations, 2000).

20. I. Nsiah-Akoto et al. Indoor radon levels and the associated effective dose rate determination at dome in the Greater Accra Region of Ghana. Research Journal of Environmental and Earth Sciences 3(2) (2011) 124.

21. Evolution of ICRP Recommendations 1977, 1990 and 2007. Changes in Underlying Science and Protection Policy and their Impact on European and UK Domestic Regulation. NEA No. 6920 (OECD, 2011) $117 \mathrm{p}$.

22. RAD-7TM Electronic Radon Detector. Manual version 6.0.1. (Durridge Company Inc., 2010).

23. Radon Measurements in School. Revised Edition. United States Environmental Protection Agency. Office of Air and Radiation (6604J). EPA Document \#402-R-92-014. July 1993.
24. A. Malanca, R. Fava, L. Gaidolfi. Indoor radon levels in Kindergartens and play-schools from the Province of Parma. J. Environ. Radioactivity 40 (1998) 1.

25. K. Dabayneh. Indoor radon concentration measurements in Tarqumia Girl schools at Western Hebron Region, Palestine. Isotope and Rad. Res. 38 (2006) 1067.

26. S. Labidi et al. Radon in elementary schools in Tunisia. Radioprotection 45 (2010) 209.

27. R.I. Obed et al. Radon measurements by nuclear track detectors in secondary schools in Oke-Ogun region, Nigeria. Journal of Environmental Radioactivity 102 (2011) 1012.

28. A.A. Abdulhussan et al. Measurement of radon concentrations for some houses in Al-Najaf city/Iraq. Iraqi Journal of Physics 11(22) (2013) 51.

29. E.J. Mohammed. Radon concentrations in some soil and air samples of dwellings in Karbala City and influencing factors on lung cancer risks using CR39. MSc Thesis (University of Kerbala College of Science, 2016).

30. F.S. Najeba, S.J. Mohamad. Higher levels of radon affect women's fertility in Iraqi Kurdistan. Polish Journal of Environmental Studies 22(4) (2013) 1163.

31. F.T. Nada, O.R. Noora, A.A. Asmaa. Measurement of indoor radon concentration in various dwellings of Baghdad Iraq. International Journal of Physics 3(5) (2015) 202.

\author{
Алі Абід Абоджасім ${ }^{1,}$, Хусен Абід Алі Мрайтіㄹ, Афнан Алі Гусайн1, Майк Вуд² \\ ${ }^{1}$ Університет Куфи, факультет фізики, Куфа, Ірак \\ ${ }^{2}$ Школа наук про навколишнє середовище та життя, Університет Салфорду, Великобританія
}

*Відповідальний автор: ali.alhameedawi@uokufa.edu.iq

\title{
ОЦІНКА ОНКОЛОГІЧНОГО РИЗИКУ ВІД РАДОННОГО ОПРОМІНЕННЯ У ДЕЯКИХ БУДІВЛЯХ ТЕХНІЧНОГО ІНСТИТУТУ КУФИ, ІРАК
}

Ряд міжнародних організацій з охорони здоров’я розглядає вплив житлового радону як другу основну причину раку легенів після куріння сигарет. Було встановлено, що бази даних щодо концентрацій радону для будівель Технічного інституту Куфи в літературі немає. Отже, існує потреба у таких вимірюваннях. Метою даного дослідження є вивчення внутрішніх рівнів радону в будівлях Технічного інституту Куфи вперше за допомогою різних методів вимірювання радону, таких як активні (RAD-7) та пасивні методи (LR-115 тип II). 78 твердотільних ядерно-трекових детекторів (SSNTD) LR-115 типу II було встановлено на чотирьох будівлях у досліджуваній області. Ці детектори накопичували опромінення протягом трьох місяців. Паралельно 3 цим було проведено 72 два активних вимірювання 3 використанням детекторів RAD-7 у тих же будинках для дослідження кореляцій між двома видами вимірювань (тобто пасивними та активними). Результати показують, що концентрації радону були загалом низькими, що коливаються від 38,4 до 77,2 Бк/м², із середнім значенням 50 Бк/м³. Середнє значення рівноважного еквіваленту концентрації радону та річної ефективної дози оцінені як 19,9 Бк/м³ та 1,2 мЗв/рік відповідно; ризик виникнення раку легенів становить приблизно 11,6 на 1 мільйон. Виявлено високу кореляцію між методами вимірювань (тобто за допомогою LR-115 типу II та RAD-7), $\mathrm{R}^{2}=0,99$, що $є$ значним при $\mathrm{P}<0,001$. Результати цієї роботи показали, що концентрація радону $\epsilon$ нижче критичного рівня, установленого Агентством охорони навколишнього середовища Сполучених Штатів Америки, 148 Бк/м³. Отже, це свідчить про відсутність радіологічної небезпеки для здоров'я. Відносно високі концентрації в деяких кабінетах можуть бути зменшені за допомогою природної вентиляції або встановленням вентиляторів із функцією поглинання.

Ключові слова: концентрація радону, надлишок ризику для легенів, будівлі Технічного інституту Куфи. 
Али Абид Абоджасим ${ }^{1, *}$, Хусен Абид Али Мрайти ${ }^{1}$, Афнан Али Гусайн ${ }^{1}$, Майк Вуд ${ }^{2}$

${ }^{l}$ Университет Куфы, факультет физики, Куфа, Ирак

${ }^{2}$ Школа наук об окружающей среде и жизни, Университет Салфорда, Великобритания

*Ответственный автор: ali.alhameedawi@uokufa.edu.iq

\section{ОЦЕНКА ОНКОЛОГИЧЕСКОГО РИСКА ОТ РАДОННОГО ОБЛУЧЕНИЯ В НЕКОТОРЫХ СТРОЕНИЯХ ТЕХНИЧЕСКОГО ИНСТИТУТА КУФЫ, ИРАК}

Ряд международных организаций по охране здоровья рассматривает влияние жилого радона как вторую основную причину рака легких после курения сигарет. Было установлено, что базы данных по концентрации радона для строений Технического института Куфы в литературе нет. Таким образом, существует потребность в таких измерениях. Целью данного исследования было изучение внутренних уровней радона в строениях Технического института Куфы впервые с помощью разных методов измерения радона, таких как активные (RAD-7) и пассивные методы (LR-115 тип II). 78 твердотельных ядерно-трековых детекторов (SSNTD) LR-115 типа II было установлено на четырех строениях в исследуемой области. Эти детекторы накапливали облучение на протяжении трех месяцев. Параллельно с этим было проведено 72 активных измерения с использованием детекторов RAD-7 в тех же строениях для исследования корреляций между двумя видами измерений (т.е. пассивными и активными). Результаты показывают, что концентрации радона были в общем низкими, от 38,4 до $77,2 \mathrm{Б \kappa} / \mathrm{m}^{3}$, со средним значением $50 \mathrm{Б \kappa} / \mathrm{m}^{3}$. Среднее значение равновесного эквивалента концентрации радона и годовой эффективной дозы оценено как 19,9 Бк/м³ и 1,2 мЗв/год соответственно; риск возникновения рака легких равен приблизительно 11,6 на 1 миллион. Обнаружена высокая корреляция между методами измерений (т.е. с помощью LR-115 типа II и RAD-7), $\mathrm{R}^{2}=0,99$, что существенно при $\mathrm{P}<0,001$. Результаты этой работы показали, что концентрация радона ниже критического уровня, установленного Агентством охраны окружающей среды Соединенных Штатов Америки, 148 Бк/м³. Таким образом, это свидетельствует об отсутствии радиологической опасности для здоровья. Относительно высокие концентрации в некоторых кабинетах могут быть уменьшены с помощью природной вентиляции или установкой вентиляторов с функцией поглощения.

Ключевые слова: концентрация радона, излишек риска для легких, строения Технического института Куфы. 